\title{
Low Prevalence of Antibody to Hepatitis G Virus Among the Risk Groups and Healthy Population of Bangladesh
}

\author{
M Siddiqua, ${ }^{1}$ AA Nawsher, ${ }^{2}$ S Tabassum, ${ }^{3}$ MN Islam ${ }^{4}$ \\ ${ }^{1}$ Dr Mahmuda Siddiqua, Associate Professor, Dept. of Microbiology, Ibn Sina Medical college, Kallyanpur, Dhaka; ${ }^{2}$ Dr Ahmed \\ Nawsher Alam, Bacteriologist, Microbiology Laboratory, Institute of Public Health, Dhaka; ${ }^{3}$ Professor Dr Shahina Tabassum, \\ Chairman, Dept. of Virology, Bangabandhu Sheikh Mujib Medical University, Dhaka, ${ }^{4}$ Professor Dr.Md Nazrul Islam, Ex \\ Chairman, Dept. of Virology, Bangabandhu Sheikh Mujib Medical University, Dhaka
}

\begin{abstract}
Hepatitis G virus (HGV) is a RNA virus, which was identified in 1995-1996 as a transfusion transmissible virus and is associated with acute or chronic hepatitis. The sero-prevalence of hepatitis $G$ virus was evaluated among various risk groups and healthy controls from Bangladesh.

A total of 252 subjects comprising of Intra-venous drug users (n-40), commercial sex workers (n-30), multiply transfused patients (n-62), hemodialysis patients (n-30), anti HCV positive patients (n-30), anti HIV positive patients (n-30) and healthy population (n-30) were included in this study. Antibody to hepatitis G virus E-2 protein was detected in the serum by Enzyme linked immunosorbent assay (ELISA). The overall antibody prevalence of HGV was $3.2 \%$. The highest prevalence $(\mathbf{1 0} \%)$ was observed among commercial sex workers, followed by intra-venous drug users (5\%). The lowest prevalence (3.3\%) was observed among each of the groups of hemodialysis patients, anti-HCV positive patients and anti-HIV positive patients. Anti-HGV antibody was not detected among any subjects from the control group. Epidemiologic data indicate that $\mathrm{HGV}$ is prevalent in risk groups though at very low prevalence.
\end{abstract}

Key words: Hepatitis $G$ virus $(H G V)$, anti- $H G V$.

\section{Introduction}

Five viruses (A-E) are usually associated with hepatitis in human. In addition to these viruses as etiological agents of hepatitis, there remain a number of patients with hepatitis in whom no virus can be identified. Two other viruses have been found to be associated with hepatitis: Hepatitis G Virus/ GB virus C, and Transfusion Transmissible Virus (TTV). ${ }^{1}$ Hepatitis $\mathrm{G}$ virus is a member of Flaviviridae with a positive sense RNA genome. ${ }^{2-4}$ Initial studies on HGV infection reported the association with acute and chronic liver diseases, including billiary duct inflammation and fulminating

Correspondence:

Dr Mahmuda Siddiqua

E-mail : mahmuda99@yahoo.com hepatitis, occurring in patients with no other known etiology. ${ }^{5}$ It is well established that $\mathrm{HGV}$ maintains a high and stable level of plasma viremia for many years, ${ }^{6}$ which indicates it's efficient and active replication. Before the establishment of antibody detection methods, prevalence rates of HGV RNA in general population varied between less than 1 to $4 \%$ in different countries. ${ }^{7}$ With the development of new tests for detection of anti-HGV antibodies about 3 to $20 \%$ of healthy people are found to have antibodies, indicating that the virus is more widely spread worldwide. In particular, rates of $\mathrm{HGV}$ seropositivity have ranged between $2-8 \%$ in Asia and North America, between 10-15\% in Europe and around 20\% in South Africa and South America. ${ }^{8}$ High prevalence rates of HGV have been reported among selected risk groups including intravenous drug users, multiply transfused patients, haemodialysis patients, hemophiliacs and individuals receiving pooled plasma or intravenous immunoglobulin. ${ }^{9}$ In Thailand, it's prevalence among healthy 
controls was 1 to $5 \%$, in thalassaemic children $32.6 \%$, asymptomatic carriers of anti-HCV $20.4 \%$, IDUs $18.2 \%$, aplastic anaemia patient $14.3 \%$, CSWs $10 \%$ and in chronic liver disease $10 \%{ }^{10}$. Diagnosis of HGV infection is usually carried out by testing serum for the viral genome and /or antiviral antibody. The presence of HGV genome in serum is evaluated by reverse transcriptase PCR (RT-PCR). Satisfactory results have been obtained using Enzyme Immuno Assay (EIA) based on recombinant E2 protein expressed on Chinese Hamster Ovarian (CHO) cell. ${ }^{8,11}$

$\mathrm{HGV}$ is transmitted by parenteral ${ }^{12}$, sexual ${ }^{13}$, and vertical ${ }^{14}$ routes. Depending on the route of transmission of $\mathrm{HGV}$, various risk groups including intravenous drug users (IDUs), commercial sex workers (CSW), multiply transfused patients (MTP), hemodialysis patients, anti-HCV positive patients, and anti-HIV positive patients were considered as study group in the present study. As no data about the prevalence of infection with $\mathrm{HGV}$ among various risk groups and the general population is available from Bangladesh, this is the first study to detect the prevalence of HGV infection.

\section{Patients and Methods:}

The study was carried on 252 subjects comprising of various population at risk. Regarding demographic characteristics of various risk groups, the intravenous drug users (IDUs) (n-40) were male, age ranged from 11 to $>40$ years; commercial sex workers (CSW) (n-30) were female, age ranged from 11 to $>$ 40 years; multiply transfused patients (MTP) (n-62) including thalassemic, haemophalic and aplastic anaemia, having history of blood transfusion for $>30$ units of blood or blood products, 36 were male and 26 were female, age ranged from 0 to $>40$ years; hemodialysis patients (n-30) were 21 male and 9 female, age ranged from 21 to $>40$ years; anti-HCV positive patients (n-30) were 21 to $>40$ years of age including 26 male and 4 female; anti-HIV positive patients (n-30) including 21 male and 9 female from 11 to $>40$ years of age and healthy population (n-30) were selected from those who had no history of apparent jaundice in life, age ranged from 21 to 40 years, of which 12 were male and 18 were female. Histories of the patients were recorded in a pre-designed data collection sheet. 3-5 $\mathrm{ml}$ of venous blood was collected in a sterile test tube aseptically by veni-puncture with informed written consent of the subjects and from the guardians of the subjects who were minor. Antibody to HGV E2 protein was detected in the serum by Enzyme linked immunosorbent assay (ELISA) using a commercially available kit (Diagnostic Automation, Inc. USA; Lot No. G 20070201 and G 20060801, Ref no. 1887-12) according to the manufacturer's instruction.

\section{Result:}

252 subjects from various risk groups were tested for antibody to $\mathrm{HGV}$ in this study, of which 8 subjects were found positive showing the overall prevalence of $\mathrm{HGV}$ was $3.2 \%$ (Table-1). Among different risk groups, highest prevalence $10 \%(3 / 30)$ of $\mathrm{HGV}$ antibody was observed among commercial sex workers (CSW) followed by $5 \%$ (2/40) among intra venous drug users (IDU). 3.3\% (1/30) subjects had HGV antibody from each of the groups of hemodialysis patients, anti-HCV positive patients and antiHIV positive patients. No antibody to $\mathrm{HGV}$ was detected among multiply transfused patients $(0 / 62)$ and the healthy populations (0/30). Considering the age, the highest $4.9 \%$ (2/41) prevalence of HGV antibody was observed among $>40$ years of age group followed by $4.3 \%$ (3/69) among 31-40 years of age group. Comparatively low prevalence of $3.1 \%$ and 2.8\% was observed in 11-20 years and 21-30 years of age group respectively. The prevalence was found $0 \%(0 / 27)$ among $<10$ years of age. The prevalence of $\mathrm{HGV}$ antibody in different sex was found $3.2 \%(5 / 156)$ in males and $3.1 \%$ $(3 / 96)$ in females.

Table 1: Prevalence of antibody to $\mathrm{HGV}$ in different groups

\begin{tabular}{|c|c|c|c|c|c|c|c|c|c|c|}
\hline \multirow{2}{*}{$\begin{array}{l}\text { Study } \\
\text { Group }\end{array}$} & \multirow[b]{2}{*}{ Up tol0 } & \multicolumn{3}{|c|}{ Age in Years } & \multirow[b]{2}{*}{$>40$} & \multicolumn{2}{|c|}{ Sex } & \multirow{2}{*}{$\begin{array}{l}\text { Total } \\
\text { Subject } \\
\text { tested }\end{array}$} & \multirow{2}{*}{$\begin{array}{l}\text { Total } \\
\text { HGV } \\
\text { positive }\end{array}$} & \multirow{2}{*}{$\begin{array}{l}\text { Prevalence } \\
\text { of } \mathrm{HGV}\end{array}$} \\
\hline & & $11-20$ & $21-30$ & $31-40$ & & Male & Female & & & \\
\hline IVDU & $00^{*}(00)^{* *}$ & $00(04)$ & 01(19) & 01(13) & $0(04)$ & $02(40)$ & $000(0)$ & 40 & 02 & $05 \% * * *$ \\
\hline CSW & $00(00)$ & $00(01)$ & $01(25)$ & $0(02)$ & $01(02)$ & $00(00)$ & $00(30)$ & 30 & 03 & $10 \%$ \\
\hline MTP & $00(27)$ & $00(23)$ & $0(06)$ & $0(05)$ & $0(01)$ & $00(36)$ & $00(26)$ & 62 & 00 & $00 \%$ \\
\hline Hemodialysis & \multicolumn{2}{|c|}{$00(00)^{\prime} 00(00)$} & $0(05)$ & $0(10)$ & $01(15)$ & $01(21)$ & $00(09)$ & 30 & 01 & $3.3 \%$ \\
\hline Anti-HCV patients & $00(00)$ & $00(00)$ & $0(03)$ & $01(09)$ & $0(18)$ & $01(26)$ & $00(04)$ & 30 & 01 & $3.3 \%$ \\
\hline Anti HIV patients & $00(00)$ & $00(00)$ & $0(08)$ & $01(18)$ & $0(01)$ & $01(21)$ & $00(09)$ & 30 & 01 & $3.3 \%$ \\
\hline Healthy population & $00(00)$ & $00(00)$ & $00(18)$ & $00(12)$ & $00(00)$ & $00(12)$ & $00(18)$ & 30 & 00 & $00 \%$ \\
\hline \multirow[t]{2}{*}{ Total } & $00(27)$ & 01(31) & $02(84)$ & $03(69)$ & $02(41)$ & $05(156)$ & $03(96)$ & 252 & 08 & $3.2 \%$ \\
\hline & $00 \%$ & $3.1 \%$ & $2.4 \%$ & $4.3 \%$ & $4.9 \%$ & $3.2 \%$ & $3.1 \%$ & & & \\
\hline
\end{tabular}

\footnotetext{
* Number of HGV positive patients

( )** Number of subjects tested

$\% * * *$ Prevalence of $\mathrm{HGV}$ antibody
}

Discussion:

Diagnosis of HGV depends on two methods; acute infection can be diagnosed by detection of HGV RNA by PCR, while past infection can be diagnosed by detection of antibody to E2 protein of the virus by ELISA. However, anti E2 antibodies to $\mathrm{HGV}$ and $\mathrm{HGV}$ RNA are almost mutually exclusive. ${ }^{15}$ It has been reported that $60 \%-70 \%$ patients develop antibodies after infection. ${ }^{16}$ As such, the detection of HGV RNA and anti-E2 is necessary to accurately define the 
prevalence of HGV infection in a population ${ }^{17}$. Our study detected HGV antibody by ELISA method only as there was no provision to detect acute infection by PCR.

In this study, the overall prevalence of HGV antibody was $3.2 \%$ (Table-I). Our study detected the highest prevalence $(10 \%)$ of HGV antibody among CSWs. Similarly, a study from Thailand found, HGV RNA in $10 \%$ of $\mathrm{CSWs}^{10}$. In contrast, a study from Taiwan reported the prevalence of HGV antibody is $23 \%$ and HGV RNA is $13 \%{ }^{18}$. Thus, it may be assumed that the predominant route of transmission of $\mathrm{HGV}$ in Bangladesh may be the sexual route.

Among the IDUs, only $2(5 \%)$ subjects were positive for HGV antibody. In a study from Taiwan, out of 76 IDUs studied, antibody to $\mathrm{HGV}$ was detected in $10(13 \%)$ subjects $^{18}$. Relatively low (8.8\%) prevalence of HGV RNA has been reported from Iran ${ }^{19}$. Since the HGV RNA test was not done, it was not possible to ascertain the prevalence of acute infection in our study. The low antibody prevalence among IDUs may be due to overall low prevalence in our country.

None of the 62 multiply transfused patients had antibody to HGV. However, 11.4\% prevalence of HGV RNA has been reported from India, ${ }^{20} 12.9 \%$ from Iran $^{19}$ and $14.2 \%$ from Brazil $^{21}$ among multi transfused patients. Since only past infection by $\mathrm{HGV}$ was detected in our study but acute infection was not carried out, further evaluation to explore into such low prevalence among multi-transfused patients in our local population is required.

Among the 30 hemodialysis patients in this study, only 1 (3.3\%) was positive for $\mathrm{HGV}$ antibody. Prevalence of antibody to $\mathrm{HGV}$ in hemodialysis patients in Japan was reported as $7.8 \%{ }^{22}-10.7 \%{ }^{23}$ and $25.7 \%$ from South Africa ${ }^{15}$. Low prevalence of hepatitis $\mathrm{G}$ virus antibody in hemodialysis patients may be due to following reasons i) immunocompetent individuals develop antibody at a much higher ratio than immunodepressed patients ${ }^{17}$, ii) $\mathrm{HGV}$ infection may be more likely to persist in hemodialysis patients and seroconversion to anti E2 may be less likely to occur $^{24}$ and iii) it was also been suggested that seropositivity for anti E2 may be short lasting after seroconversion among hemodialysis patients. ${ }^{22}$ However further studies must be carried out to substantiate this hypothesis.

Of the HCV positive patients in this study, 1 (3.3\%) was found to be positive for $\mathrm{HGV}$ antibody. A 4\% prevalence of $\mathrm{HGV}$ antibody and 6\% HGV RNA prevalence was reported among HCV positive patients from Turkey, ${ }^{25}$ which is similar to the present study. Similarly, among HIV positive patients only $1(3.3 \%)$ were positive for HGV antibody. Very high prevalence $56.8 \%$ and $46 \%$ of $\mathrm{HGV}$ antibody among HIV positive people was reported from Germany ${ }^{26}$ and the USA. ${ }^{27}$ Low prevalence of $\mathrm{HGV}$ antibody among risk groups indicate overall low prevalence in our country.

Our study did not observe any HGV antibody among the healthy populations. Similarly studies from Belgium ${ }^{28}$ and India ${ }^{20}$ did not observe HGV antibody or HGV RNA among healthy controls. These findings indicate that prevalence of $\mathrm{HGV}$ infection is absent or low among the general population. However, overall low prevalence of $\mathrm{HGV}$ antibody in the general population may perhaps reflect the low prevalence in the risk groups.

We found that $\mathrm{HGV}$ infection was more frequent among individuals who were older, than younger group. In our study highest $4.9 \%$ prevalence was seen above 40 years of age group. Similar findings were seen from studies in Iran 19, 29. There was no significant difference seen in this study about the prevalence of $\mathrm{HGV}$ among the male $(3.2 \%)$ and female $(3.1 \%)$.

The present study suggests that $\mathrm{HGV}$ is prevalent among Bangladeshi population. However further studies with larger sample size should be carried out from time to time to obtain a dependable conclusion.

\section{Reference}

1. Sehgal R. and Sharma A. 2002 Hepatitis G virus:current perspectives. Indian J Pathol Microbiol; 45:123-128

2. Simons JN, Leary TP, Dawson GJ et al. 1995 Isolation of novel virus -like sequences associated with human hepatitis. Nat Med; 1: 564-569.

3. Linen J, Wages JJr, Zhang-Keck ZY et al. 1996 Molecular cloning and disease associated on hepatitis $G$ virus: $A$ transfusion-transmissible agent. Science; 27: 505-508.

4. Learly TP, Muerhoff AS and Simons JN. 1996 Sequence and genomic organization of GBV-C: a novel member of Falviviride associated with human no A-E hepatitis. J Med Virol; 48: 60-67

5. Heringlake $\mathrm{S}$, Osterkamp S, Trautwein C et al. 1996 Association between fulminant hepatic failure and a strain of GBV virus C. Lancet; 348: 1626-1629.

6. Pessoa MG, Terrault NA, Ferrell LD. 1997 Hepatitis G virus in patients with cryptogenic liver disease undergoing liver transplantation. Hepatology; 25: 1266-1270

7. Minton J. 1998 Transfusion associated Hepatitis G virus infection. Rev Med Microbiol; 9: 207-215

8. Dille BJ, Surwoy TK, Gutierrez GA et al. 1997 An ELISA for detection of antibodies to the $\mathrm{E} 2$ protein of GB virus C. J Infect Dis; 175 : 458-461.

9. Feucht HH, Zollner B, Polywka S et al. 1997 Distribution of Hepatitis G viremia and antibody response to recombinant proteins with special regard to risk factors in 709 patients. Hepatology; 26: 491-494. 
10. Poovorawan Y, Theamboonlers A, Chongerisawat V and Jantaradsamee P.1998 Prevalence of infection with hepatitis G virus among various groups in Thailand. Annal of Tropical Medicine \&Parasitology; 92:89-95

11. Tacke M, Kyosawa K, Stark K et al. 1997 Detection to a putative hepatitis virus $\mathrm{G}$ envelope protein. Lancet; 349: 318320.

12. Hadziyannis S, Wages J, Kim JP et al., 1995 Frequency of Viremia with a new hepatits virus (HGV) in patients with liver disease and in groups at high risk of exposure to blood and blood products. J Hepatol; 23: 78A

13. Hess G 1998 In Proceedings of International Symposium on ' Transfusion associated hepatitis' - Diagnosis, Treatment and Prevention (eds Sarin, S. K and Hess G) CBS Publishers, New Delhi, pp 126-138.

14. Feucht HH , Zollner B, Polywka S, and Laufs R. 1996 Vertical transmission of hepatitis G. Lancet; $347: 615$

15. Sathar MA Soni PN, Naicker S et al., 1999 GB virus C / HGV infections in KwaZulu Natal, South Africa. J Med Virol ; 59: $38-44$.

16. Warren Levinson. Medical Microbiology \& Immunology: Examination \& Board Review. The McGraw-Hill Companies, Inc. $8^{\text {th }}$ edn.USA, 2005:292.

17. Lefrere JJ, Roudot-Thoravel F, Morand-Joubert L et al., 1999 Carriage of GB virus C / hepatitis G virus RNA is associated with a slower immunologic, virologic, and clinical progression of Human Immuno deificiency virus disease in coinfected persons. J Infect Dis; 179: 783-789

18. Hwang SJ, Chu CW, Lu RH et al. 2000 Prevalence of GB virus $\mathrm{C} /$ hepatitis G virus-RNA and antienvelope antibody in high risk population in Taiwan. J Gastroenterol Hepatol; 15: 11711175 .

19. Amini S, Andalibi S, Mahmoodabadi et al. 2005 Prevalence of Hepatitis $G$ virus in high risk groups and blood donors in Tehran, Iran. Iranian J Publ Health; 34: 41-46.

20. Arankalle VA, Deshmukh TM, Chobe LP et al. 2001 Hepatitis $G$ virus infection in India: prevalence and phylogenetic analysis based on 5' non coding region. Indian J Gastroenterol ; 20:13-17.

21. Watanabe MA, Milanezi CM, Silva WA Jr et al.2003 Molecular investigation of GB virus C RNA in hemodialysis and thalassemics patients from Brazil. Ren Fail; 25:67-75.

22. Okuda M, Hino K, Korenaga M et al., 2000 Hepatitis G viremia and antibody response to $\mathrm{E} 2$ protein of hepatitis $\mathrm{G}$ Virus in hemodialysis . J Clin Gastroenterol; 30: 425-428

23. Furusyo N, Havaashi J, Aribama I et al., 2000 Lower HGV infection prevalence comppared to hepatitis B and C virus infection prevalences. Dig Dis Sci; 45:188-195

24. Masuko K, Mitsui T, Iwano K et al. 1996 Infection with hepatitis $\mathrm{GB}$ virus $\mathrm{C}$ in patients on maintenance hemodialysis. N Engl J Med; 334: 1485-1490.
25. Kaya S, Cicioglu AB, and Demirci M. 2004 The prevalence of $\mathrm{HGV}$ in patients with $\mathrm{HBV}$ and $\mathrm{HCV}$ infection. Mickrobiyol Bul;38:421-427

26. Heringlake S, Ockenga J, Tillmann HL, Trautwein C et al., 1998 Hepatitis G virus C/ Hepatitis G virus infection: A favorable prognostic factor in human immunodeficiency virus infected patients? J Infect Dis; 177:1723-1726

27. Carolyn FW, Xiang J, Liu C and Zdunek D. 2004 Persistent GB virus $\mathrm{C}$ infection and survival in HIV infected men. $N$ Engl J Med ;350:981-990.

28. Sheng L, Widvastuti A, Kosala H et al., 1998 High prevalence of hepatitis $\mathrm{G}$ virus infection in patients undergoing chronic hemodialysis. Am J Kidney Dis; 31:366-368.

29. Sedigheh Amini Kafi-Abad, Shahram Samiei, Ali Talebian et al.,2009 Hepatitis G Virus Infection in Iranian Blood Donors and High-Risk Groups. Hepatitis Monthly; 9(4): 282-286. 